\title{
Prevalence and knowledge of urinary incontinence and possibilities of treatment among low-income working women
}

\author{
Prevalência e conhecimento sobre incontinência \\ urinaria e possibilidades de tratamentos entre \\ mulheres trabalhadoras de baixa renda
}

\author{
Amabily Carolline Zago, Maria Angelica Saquete Fambrini, Elaine Priscila Garcia Silva, \\ Alberto De Vitta, Marta Helena Souza De Conti, Gabriela Marini*
}

Universidade do Sagrado Coração (USC), Bauru, SP, Brazil

\begin{abstract}
\footnotetext{
AMZ: undergrad student, e-mail: amabily_carolline@hotmail.com

MASF: MS student, e-mail: mariangelica435@hotmail.com

EPGS: MS student, e-mail: elainepriscila@hotmail.com

ADV: PhD, email:albvitta@gmail.com

MHSC: PhD Prof, email: madeconti@yahoo.com.br

GM: PhD, e-mail: gacamarini@yahoo.com.br
}

Introduction: Urinary incontinence (UI) can affect women's lives in all areas, including in the occupational context, due to an uncomfortable workplace, incorrect positions for long periods of time and the handling of heavy items. Another worrying aspect is that the knowledge about urinary incontinence, in the health area, and its forms of treatment is still small among the low-income population. Objective: To verify the prevalence and knowledge about urinary incontinence and treatment possibilities among low-income working women. Methods: A cross-sectional study carried out on working women of a poultry processing plant. Results: The study included 136 women with an average age of $33.7 \pm 9.7$ years; body mass index of $26.6 \pm 5.6 \mathrm{~kg} / \mathrm{m}^{2}$; parity of $2.1 \pm 1.1$ children; monthly income of $2.3 \pm 1$ minimum wages. Of those interviewed, $63.9 \%$ were white; $44.8 \%$ had incomplete primary education; $52.9 \%$ were single; $53.6 \%$ underwent cesarean section delivery; and of those who underwent normal labor delivery, 86.6\% underwent episiotomy. The prevalence of urinary incontinence was found to be $2.9 \%$, and among the women affected, two 
reported that UI led to sexual, social, water and occupational restriction, and one of them believes that UI interferes with her concentration and productivity in the workplace. Regarding health knowledge, $46.3 \%$ had never heard of urinary incontinence before, and more than half (66.1\%) did not know about the existence of medical treatment. All women interviewed (100\%) were unaware of the existence of physiotherapeutic treatment. Conclusion: The prevalence of urinary incontinence was among those interviewed was small, however, the knowledge about the symptoms and possibilities of medical, and mainly physiotherapeutic treatment. is scarce among these women. This study allows to alert and to guide the health professionals and the society about the importance of actions that promote health education in the low income population, besides allowing these women to prevent or seek the appropriate treatment in order to guarantee a better quality of life.

Keywords: Urinary Incontinence. Health Education. Women's Health. Occupational Health.

\section{Resumo}

Introdução: A incontinência urinária pode afetar a vida da mulher em todos os âmbitos, inclusive no contexto ocupacional, devido a ambientes desfavoráveis, posições incorretas por longos períodos e carregamento de pesos. Outro aspecto preocupante é que o conhecimento em saúde sobre a perda urinária e suas formas de tratamento ainda é pequeno entre a população de baixa renda. Objetivo: Verificar a prevalência e o conhecimento sobre incontinência urinária e possibilidades de tratamentos entre mulheres trabalhadoras de baixa renda. Métodos: Trata-se de estudo transversal, realizado em mulheres trabalhadoras em uma empresa frigorífica de aves. Resultados: Participaram do estudo 136 mulheres com média de idade de 33,7 \pm 9,7 anos; índice de massa corporal de 26,6 $\pm 5,6 \mathrm{Kg} / \mathrm{m}^{2}$; paridade de 2,1 $\pm 1,1$ filhos; renda mensal de 2,3 \pm 1 salários mínimos. Das entrevistadas, 63,9\% eram brancas; 44,8\% com ensino fundamental incompleto; 52,9\% eram solteiras; 53,6\% realizaram parto cesárea; e das mulheres que fizeram parto vaginal, 86,6\% realizaram episiotomia. A prevalência de perda urinária encontrada foi de 2,9\%, e entre as mulheres afetadas, duas relataram que a IU levou a restrição sexual, social, hídrica e ocupacional, sendo que uma delas, acredita que a perda de urina interfere na concentração e na sua produtividade no trabalho. Sobre o conhecimento em saúde, 46,3\% nunca ouviram falar sobre o assunto da incontinência, sendo que mais da metade $(66,1 \%)$ não sabiam da existência de tratamento médico e todas as entrevistadas (100\%) não conheciam a existência de tratamento fisioterapêutico. Conclusão: A prevalência de IU em mulheres trabalhadoras de baixa renda no setor frigorífico foi pequena, entretanto, o conhecimento sobre a incontinência urinária e as possibilidades de tratamento é escasso entre estas mulheres. Este estudo permite alertar e orientar os profissionais da saúde e a sociedade sobre a importância de ações que promovam educação em saúde na população de baixa renda, além de permitir que estas mulheres se previnam ou procurem o tratamento adequado e garantam melhor qualidade de vida.

Palavras-chave: Incontinência Urinária. Educação em Saúde. Saúde da Mulher. Saúde do Trabalhador.

\section{Introduction}

Defined as any involuntary loss of urine (1), Urinary Incontinence (UI) is a frequent condition, with an estimated prevalence of $52.3 \%$ in Brazilian women (2) and having projected costs amounting to US $\$ 82.6$ billion in 2020 in the United States (3). The UI symptoms lead to different problems such as psychological changes and disturbances in personal, sexual, social and professional relationships, negatively influencing the quality of life of this population (4).

With the evolution of technology, women occupied a greater space in the labor market, and the concern with the quality of life of these workers became reality. The UI symptoms can have negative implications on occupational activities such as loss of concentration, low productivity, stress and fatigue (5). In certain 
situations, the workers choose not to perform some work activities to avoid losses and still adhere to strategies for UI management, such as more frequent changes of clothes or visits to the bathroom and the use of sanitary pads (5).

The regulation of worker's health in Brazil has had recent and important initiatives to consolidate actions in this area. In this sense, the National Worker Safety and Health Policy (6) and the National Worker Health Policy (7) represent advances in defining guidelines, strategies and mechanisms for management, financing, and social control that guide intra- and intersectoral approaches to workers' health. Women's health is also a matter of great concern at the federal level, which in 2011 elaborated the "National Policy for Integral Attention to Women's Health - Principles and Guidelines", which covers care for women based on an expanded perception of their context of life, of the moment in which they present a particular demand, as well as of their singularity and conditions as capable and responsible subjects for their choices (8).

Some studies show the prevalence of UI in working women. The prevalence found varied among studies, being established between 19\% (9) and $31 \%(10)$ among military women in the United States; $21 \%$ among women working in an academic center (11); 29\% among workers of a manufacturing company (12); 34.7\% in nurses in Japan (13); and from $27.5 \%$ (14) to $37.4 \%$ (5) in nurses, technicians and nursing assistants in Brazil. As a consequence of leaking urine in the workplace, professionals reported a lack of concentration (18.2\%), low productivity (21.2\%) (5), and lifestyle restrictions, especially those related to work tasks and sexual activities (14).

Concerning knowledge, it is known that income directly affects health, providing women with healthcare products and services, such as medical consultations, medicines, preventive examinations and appropriate treatment, besides better housing possibilities and educational conditions (15).

No studies on the prevalence and knowledge about UI and their forms of treatment were identified in low-income working women regularly employed in slaughterhouses. This occupational sector has attracted the attention of health and occupational safety professionals, mainly because it is a sector of significant importance in the national economy, which encompasses expressive low-cost labor, and presents working conditions that involve great physical effort due to the lifting of weight and repetitive motion tasks, the requirements of production system that operates sequentially, is fragmented and subject to the cadence imposed by the machines (16).

Thus, in the absence of reports in the literature, to study the prevalence and knowledge about UI in economically active and low-income women is to unite two current concerns of the public policies pointed out by the Women and Worker Health Program, in such a way as to improve the Health Education Program and to provide the tracking of this symptom that directly affects the quality of life of working women. Therefore, the aim of this study was to verify the prevalence and knowledge about urinary incontinence and its forms of treatment among low-income working women.

\section{Methods}

This cross-sectional study was carried out with low-income working women, employees of a poultry slaughterhouse, in the countryside of the state of São Paulo, from August to December 2015. Ethical considerations were based on the use of the material for scientific purposes, with the confidentiality of the women's identities, free of coercion or conflict of interests of the institution or of people involved in the project. The women were previously informed and the data were only collected under express consent in a specific form (Free and Informed Consent Term FICT, according to resolution 466/12 of the National Health Council of the Ministry of Health - Brazil). The study was approved by the Research Ethics Committee of the Universidade do Sagrado Coração, under the committee's opinion $n^{\circ}$ 1.045.187.

Women who worked in the company for more than twelve months, and agreed to participate in the survey were included in the study. All departments of the company were evaluated, except for the administrative, storage and loading sectors.

All participating women responded to a structured questionnaire, developed by the authors, made up of sociodemographic (age, ethnicity, schooling, marital status and family income), anthropometric (weight, height), obstetric (number of pregnancies and births, type of delivery, episiotomy), and clinical aspects (age of menarche and menopause, use of hormone replacement therapy, constipation, abdominal surgeries, neurological diseases, presence of 
comorbidities such as diabetes mellitus and systemic arterial hypertension and use of medications); occupational issues such as type of work and working conditions (function, weight lifting and predominant work position); working hours (working time in the company and in the current occupation and work load) and urinary habits during working hours.

The knowledge about UI and its forms of treatment was verified by means of closed dichotomous questions elaborated by the authors: have you heard about urinary incontinence yet?; do you know that there is medical treatment for UI?; do you know that there is physiotherapeutic treatment for UI?. Women who reported urinary loss were also asked if they sought any treatment for the problem and whether urinary loss has led to some sort of sexual, social, water and occupational restriction.

The prevalence of UI was evaluated through reports of involuntary loss of urine, according to the recommendations of the Society of Urinary Continence (1). Women with symptoms of urinary loss also responded to the validated International Consultation on Incontinence Questionnaire - Short Form (ICIQ-SF) questionnaire, which verifies the impact of UI on the quality of life, quantifies the loss and urinary frequency, and classifies UI into urinary stress, urge incontinence or mixed urine (17).

After completing the data collection, an educational pamphlet on UI was distributed to the main sectors of the company, explaining the possibilities of prevention and treatment for the symptom.

\section{Statistical analysis}

The collected data were submitted to descriptive statistical analysis and its results were presented through the distributions of absolute and relative frequencies, mean and standard deviation, in tables.

\section{Results}

The company had 271 regularly employed workers, with at least a one-year labor contract, and an average of 4.9 years of exposure to occupational conditions. In order to avoid interfering in the productivity of the sectors, 147 women were allowed to participate in the survey, of whom 11 refused, totaling 136 workers interviewed.
The average age was $33.7 \pm 9.7$ years, the body mass index was $26.6 \pm 5.6 \mathrm{~kg} / \mathrm{m}^{2}$ and parity was $2.1 \pm 1.1$ children. The average monthly income found was $2.3 \pm 1$ minimum wages. Other sociodemographic, obstetrical, clinical and lifestyle data are presented in Table 1.

Table 1 - Distribution of the women according to sociodemographic, obstetrical, clinical and behavioral features

\begin{tabular}{|c|c|c|}
\hline Features & $\mathrm{n}$ & $\%$ \\
\hline \multicolumn{3}{|l|}{ Race (\%) } \\
\hline White & 87 & $63,9 \%$ \\
\hline Black & 25 & $18,3 \%$ \\
\hline Brown & 24 & $17,6 \%$ \\
\hline \multicolumn{3}{|l|}{ Scholarity } \\
\hline Elementary School degree (Incomplete) & 61 & $44,8 \%$ \\
\hline Elementary School degree (Complete) & 4 & $2,9 \%$ \\
\hline High School degree (Incomplete) & 17 & $12,5 \%$ \\
\hline High School degree (Complete) & 54 & $39,7 \%$ \\
\hline \multicolumn{3}{|l|}{ Marital Status } \\
\hline Single & 72 & $52,9 \%$ \\
\hline Married & 64 & $47,1 \%$ \\
\hline \multicolumn{3}{|l|}{ Obstetrical Variables } \\
\hline \multicolumn{3}{|l|}{ Nulliparous } \\
\hline Multiparous & 39 & $28,6 \%$ \\
\hline Normal Labor Delivery & 34 & $35,0 \%$ \\
\hline Cesarean Section Delivery & 52 & $53,6 \%$ \\
\hline Combined Procedures & 11 & $11,4 \%$ \\
\hline Episiotomy & 39 & $86,6 \%$ \\
\hline \multicolumn{3}{|l|}{ Clinical and behavioral variables } \\
\hline Menopause & 6 & $4,4 \%$ \\
\hline Hormone Replacement & 2 & $2,2 \%$ \\
\hline Family History with UI & 30 & $22,0 \%$ \\
\hline Physical Exercises Activity & 23 & $16,9 \%$ \\
\hline Intestinal Constipation & 46 & $33,8 \%$ \\
\hline Chronic Cough & 7 & $5,1 \%$ \\
\hline Arterial Hypertension & 17 & $12,5 \%$ \\
\hline Smoking & 11 & $8,0 \%$ \\
\hline Alcohol Consumption & 0 & $0 \%$ \\
\hline Caffeinated Beverages Consumption & 96 & $70,5 \%$ \\
\hline
\end{tabular}

Women who reported urine loss were characterized as obese (BMI $\left.=31 \pm 4.9 \mathrm{~kg} / \mathrm{m}^{2}\right)$, with age ( $42.5 \pm 5$ years) and parity averages ( 4.5 \pm 0.5 births) superior to those who did not present 
the problem. It is noteworthy that all women who presented urinary loss underwent at least three normal labor deliveries and one episiotomy.

Regarding the occupational data, the average time of activities in the company is $58.65 \pm 62.13$ months, being $34.66 \pm 39.76$ months in the current function. As for the predominant work position, $96.3 \%$ of the women stand and $44.11 \%$ carry loads of 5 to 20 kilos.

The prevalence of symptoms of urinary loss was reported by only four $(2.9 \%)$ of the women. Regarding the health knowledge of the interviewees in relation to UI, $46.3 \%$ had never heard about it, and the majority $(66.1 \%)$ reported unfamiliarity with the possibility of medical treatment, and all of them $(100 \%)$ had never heard about the physiotherapeutic treatment for UI (Table 2).

Table 2 - Prevalence and knowledge about UI among interviewed women

\begin{tabular}{lcc}
\hline Questions & $(\mathrm{n}=\mathbf{1 3 6})$ & $\mathbf{\%}$ \\
\hline UI Prevalence & 4 & $2,9 \%$ \\
Never heard about UI & 63 & $46,3 \%$ \\
Don't know there's medical treatment for UI & 90 & $66,1 \%$ \\
$\begin{array}{l}\text { Don't know there's physiotherapeutic } \\
\text { treatment for UI }\end{array}$ & 136 & $100 \%$ \\
\hline
\end{tabular}

Note: $\mathrm{UI}=$ Urinary Incontinence.

Among the four women who reported UI, two of them showed urgent UI, one mixed and one by stress, by the answers collected via ICIQ-SF questionnaire. All of them reported losses of small amount, either once a week or on a daily basis.

Two women who complained about urinary loss also reported that UI led them to sexual, social, water and occupational restrictions. One of them believes that the loss of urine interferes with her concentration and productivity at work. Three workers could not tell which event triggered their loss of urine, and one of them believed it to be related to work.

Among the four women who reported urine loss, none of them talked to their doctor about the problem or sought treatment.

During work hours, it was observed that the average number of urinations of the continent women were $3.04 \pm 1$ times and of the incontinent $5.5 \pm 0.5$ times. In relation to the number of daily urinations, the continent women presented an average of $6.5 \pm 1.89$ and the incontinent $9 \pm 3.16$ times. No woman reported making use of sanitary pads. Most of the women $(66.9 \%)$ reported that the bathroom is close to the workplace and $48.5 \%$ believe that they waste time at work when they need to stop the activity to go to the bathroom.

\section{Discussion}

No studies were found in the literature that investigated the prevalence and knowledge about UI and its forms of treatment in low-income working women in the area of slaughterhouses. In the present study, although the prevalence of UI was not representative, due to some associated occupational factors, we are struck by the fact that $46.3 \%$ of women had never heard about UI, $66.1 \%$ were unaware of the existence of medical treatment and $100 \%$ were unaware of the existence of physiotherapeutic treatment for urinary loss.

The low prevalence of UI found in this study may be related to the average age of this population which is 33.7 years, being $42.6 \%$ of these women between 18 and 30 years old. Age is considered the main risk factor for female UI, with prevalence of $52.3 \%$ among Brazilian women over 50 years of age (2). In Turkey, the average age of the highest UI prevalence was 48.7 years (18) and in Portugal only $11.5 \%$ of the women under 39 years of age had UI (19). In Japanese nurses, the highest prevalence of UI was between 45 and 49 years of age (13), in the manufacturing industry it was 44.7 years and in employees of an academic center it was 45.2 years (11).

The average age found also explains why only $4.4 \%$ of the women were in menopause, a relevant factor for a low prevalence of UI. After logistic regression analysis, the risk of UI increased 2.6 times with menopause (18) and the average age of patients with UI seen in a public urogynecological physiotherapy service in Brazil was $55.3 \pm 12.9$ years, $66.8 \%$ of the patients were in the postmenopausal period and $33.2 \%$ in the premenopausal period (20).

Another factor related to the low prevalence of UI is the BMI found in this study. Higher BMI values are directly related to a higher prevalence of UI (21). Aydin et al. (22) found that a high BMI $\left(>27.4 \mathrm{~kg} / \mathrm{m}^{2}\right)$ increased the risk of urgency $(\mathrm{P}<0.001 ; \mathrm{OR}, 1.06)$, nocturia $(\mathrm{P}<0.001 ; 0 \mathrm{R}, 1.06)$ and urinary frequency $(\mathrm{P}=0.009 ; \mathrm{OR}, 1.04)$ (22). Within the occupational context, in the manufacturing industry, the average BMI among women was $29.44 \mathrm{~kg} / \mathrm{m}^{2}$ (12). 
In a literature review, with 22 cohort studies, it was shown that at least five etiological factors can be considered to explain the occurrence of stress UI: genetic factors, obesity, age, pregnancy and normal labor delivery (23). In a multicenter cross-sectional study in the South and Southeast regions of Brazil, with 495 women postpartum, $71 \%$ of them had UI in the last four weeks of pregnancy. The factors associated with UI were: four or more children (OR $=4.93,95 \%$ CI 2.15-11.32), obesity (OR $=4.22$, $95 \%$ CI 2.09-8.54), low scholarity (OR $=2.99,95 \% \mathrm{CI}$, 1.74-5.12), previous normal labor delivery ( $\mathrm{OR}=2.59$, 95\% CI 1.58 - 4.24) (24).

The lower parity and the high prevalence of cesarean deliveries in this population studied may also explain the large number of continent workers. As continent women in this study had an average parity of 2.1, the average number of incontinent women was 4.5 children. The risk of UI increases 3.4 times with normal labor delivery and 4.3 times with multiparity (18).

Despite the negative implications for maternal and child health, Liu et al. (21) still found that cesarean section $(\mathrm{OR}=0.42,95 \% \mathrm{CI} 0.36-0.49, \mathrm{P}<0.01)$ and normal labor delivery with episiotomy (OR $=0.19$, $95 \%$ CI $0.15-0.239, \mathrm{P}<0.011$ ) are protective factors for UI. In our study, $53.6 \%$ of deliveries were cesareans and $86.7 \%$ of women underwent episiotomy during vaginal delivery, which is considered obstetric violence and contradicts the current recommendations of the World Health Organization (WHO), which recommends that a maximum of $15 \%$ of childbirths should occur by cesarean surgery (25). However, our data are very similar to the rest of the country, and according to DATASUS, the rate of cesarean sections among live births in 2011 was $53.88 \%$ (26).

Amaral et al. (19), related UI symptoms to smoking and alcohol consumption ( $\mathrm{p} \leq 0.02$ ) (19); however, these two habits were not expressive in our study (none reported using alcoholic beverages and only $8 \%$ were smokers).

Among the four women who reported urine loss $(2,9 \%$ of the total), none talked to their doctor about this problem, corroborating with other studies that point out that most women with UI do not seek medical treatment (27 - 30). According to Higa et al., (27) the search for medical treatment for UI was reported by only $21 \%$ of hospital employees, that is, the percentage was low even in the case of health professionals. $79 \%$ of women who did not seek treatment reported several reasons for not doing so, including: sporadic urine loss and in small volumes and the belief that UI is a common problem among women (27).

Other reasons for not seeking treatment are the fact that women feel that the symptoms do not deserve medical attention, because they are not uncomfortable or painful; the lack of time to consult a doctor, and not feeling comfortable to talk about symptoms with the doctor. Most women with UI do not report the complaint if they are not objectively questioned (28). Most women believe that the subject of UI should be hidden from other people in their conviviality, which prevents the search for treatments. These women coexist with fear and shame, preferring to keep silent instead of asking for help, and consequently isolate themselves as a form of protection (31).

Being 3.04 times the average number of daily urinations during the workday, it is in line with the breaks offered by the company during the eight-hour journey. Free breaks are offered three times a day (twice in the morning and once in the afternoon) for 20 minutes so employees can go to the bathroom and drink water. Most women (66.9\%) report that the bathroom is close to the workplace, but $48.5 \%$ believe that they waste time at work when they need to stop the activity to go to the bathroom. These data corroborate with the results obtained by another study, with community health agents that restrict access to the toilet because they are too far away from the unit, and nurses and nursing technicians, who do not interrupt the flow of care from the unit to empty the bladder depending on the number of people waiting to use the bathrooms, creating inappropriate urinary habits related to occupational activities (32).

Half of the women who complained of urinary loss reported that UI led to sexual, social, water and occupational restrictions. One of them believes that urine loss interferes with her concentration and productivity at work, which is in agreement with the study by Higa et al. (27), who also concluded that daily exposure to urine loss in the presence of co-workers can cause stress, embarrassment and impairment of occupational concentration and performance (27). The strategies used to reduce losses during work and avoid urine odor were: keeping the bladder empty, using sanitary pads, restricting fluid intake, emptying the bladder frequently, using perfume, and taking a quick shower after urinating (14). 
The literature points to heavy work as a possible risk factor for UI, since it overloads the pelvic floor muscles $(21,33)$. In a study carried out in 2012, with 452 women diagnosed with UI in the city of São Paulo, it found a significant difference in relation to endurance of the pelvic floor between different classes of professions. Patients who worked as maids presented lower endurance of the pelvic floor than patients who exercised professional activity sitting $(\mathrm{p}<0.05)(20)$.

In the present study, despite the occupational context, the company's automation occurred in 2012, which implies a lower physical requirement and less worker's wear and tear. In the company, there are also no women working in the warehousing and loading sectors, that is, jobs that require a lot of physical strength are performed by men. Another positive aspect is that the company performs the activities relay within each sector daily, allowing the worker not to remain in the same activity for a long time.

One of the great results of this research was the lack of knowledge about the subject of UI and its forms of treatment among low-income working women. Of the participants, $46.3 \%$ had no knowledge of the subject of the UI and none of the 136 interviewees (100\%) were aware of the existence of physiotherapeutic treatment for UI. These data elicit the great importance of Health Education programs for the low-income population, in order to promote awareness about a little-known symptom, its forms of treatment and the importance of physical therapists to be recognized as the first line in the treatment of the UI (34). These data also bring to discussion the importance of recognizing the physiotherapy in women's health.

Figueiredo et al. (32) carried out a training session for the employees of a health clinic, where the types of UI, risk factors, therapeutic possibilities and preventive measures were discussed, including attention to urinary and intestinal habits and training of the pelvic floor muscles. The program instrumented the employees to develop self-care and to identify the need for assistance to the users, and the information, provided by trained professionals in easy and comprehensible language, provided a greater capacity to identify the problem and the consequent implementation of the therapeutic project for women with UI (32).
The implementation of educational programs within companies can be a viable and effective alternative. The promotion of continence involves informing and educating the public and health professionals that having incontinence is not inevitable or shameful, but rather that there is treatment. Prevention should include education about changes in lifestyle, the normal functioning of the urinary tract, and how to find the appropriate treatment. Primary prevention should be the goal of all health professionals (35).

\section{Conclusion}

The prevalence of UI in low-income women in the slaughterhouse sector was small, however, knowledge about urinary incontinence and treatment possibilities are scarce among these women. This study makes it possible to alert and guide health professionals and society about the importance of actions that promote health education in the lowincome population, besides allowing these women to prevent or seek the appropriate treatment in order to guarantee a better quality of life.

\section{References}

1. Abrams P, Andersson KE, Birder L, Brubaker L, Cardozo L, Chapple C, et al. Fourth International Consultation on Incontinence Recommendations of the International Scientific Committee: Evaluation and treatment of urinary incontinence, pelvic organ prolapse, and fecal incontinence. Neurourol Urodyn. 2010;29(1):213-40.

2. Reigota RB, Pedro AO, Machado VSS, Costa-Paiva L, Pinto-Neto AM. Prevalence of urinary incontinence and its association with multimorbidity in women aged 50 years or older: A population-based study. Neurourol Urodyn. 2016;35(1):62-8.

3. Coyne KS, Wein A, Nicholson S, Kvasz M, Chen CI, Milsom I. Economic burden of urgency urinary incontinence in the United States: a systematic review. J Manag Care Pharm. 2014;20(2):130-40. 
4. Stadnicka G, Łepecka-Klusek C, Pilewska-Kozak A, Jakiel G. Psychosocial problems of women with stress urinary incontinence. Ann Agric Environ Med. 2015;22(3):499-503.

5. Ribeiro J. Prevalência e fatores associados de incontinência urinária em profissionais de enfermagem de um hospital universitário [master's thesis]. Ribeirão Preto: Universidade de São Paulo; 2011.

6. Brasil. Ministério da Saúde. Política nacional de segurança e saúde no trabalho. Brasília; 2011.

7. Brasil. Ministério da Saúde. Política nacional de saúde do trabalhador e da trabalhadora. Brasília; 2012.

8. Brasil. Ministério da Saúde. Secretaria de Atenção à Saúde. Política Nacional de Atenção Integral à Saúde da Mulher. Brasília; 2011.

9. Larsen WI, Yavorek TA. Pelvic organ prolapse and urinary incontinence in nulliparous women at the United States Military Academy. Int Urogynecol J Pelvic Floor Dysfunct. 2006;17(3):208-10.

10. Davis G, Sherman R, Wong MF, McClure G, Perez $\mathrm{R}$, Hibbert M. Urinary incontinence among female soldiers. Mil Med. 1999;164(3):182-7.

11. Palmer MH, Fitzgerald S, Berry SJ, Hart K. Urinary incontinence in working women: an exploratory study. Women Health. 1999;29(3):67-82.

12. Kirkland VL, Palmer MH, Fitzgerald ST. Incontinence in a manufacturing setting: women's perceptions and responses. Public Health Nurs. 2001;18(5):312-7.

13. Araki I, Beppu M, Kajiwara M, Mikami Y, Zakoji $\mathrm{H}$, Fukasawa $\mathrm{M}$, et al. Prevalence and impact on generic quality of life of urinary incontinence in Japanese working women: assessment by ICI questionnaire and SF-36 Health Survey. Urology. 2005;66(1):88-93.

14. Higa R, Lopes M. The impact of urinary incontinence on female nursing personnel. Rev Bras Enferm. 2007;60(2):213-6.

15. Santos AMA, Jacinto PA, Tejada CAO. Causalidade entre renda e saúde: uma análise através da abordagem de dados em painel com os estados do Brasil. Estud Econ. 2012;42(2):229-61.
16. Vasconcellos MC, Pignatti MG, Pignatti WA. Emprego e Acidentes de Trabalho na Indústria Frigorífica em Áreas de Expansão do Agronegócio, Mato Grosso, Brasil. Saúde Soc São Paulo. 2009;18(4):662.

17. Tamanini JT, Dambros M, D'Ancona CAL, Palma PCR, Netto Jr NR. Validação para o português do "International Consultation on Incontinence Questionnaire - Short Form" (ICIQ-SF). Rev Saude Publica. 2004;38(3):438-44.

18. Akkus Y, Pinar G. Evaluation of the prevalence, type, severity, and risk factors of urinary incontinence and its impact on quality of life among women in Turkey. Int Urogynecol J. 2016;27(6):887-93.

19. Amaral MO, Coutinho EC, Nelas PA, Chaves CM, Duarte JC. Risk factors associated with urinary incontinence in Portugal and the quality of life of affected women. Int J Gynaecol Obstet. 2015;131(1):82-6.

20. Feitosa S, Santos ACC, Yuaso DR, Alves GA, Sartori MGF, Girão MBC, et al. Perfil clínico, funcional e sociodemográfico das pacientes com incontinência urinária atendidas em um serviço público de fisioterapia uroginecológica. Fisioter Bras. 2012;13(2):96-101.

21. Liu B, Wang L, Huang SS, Wu Q, Wu DL. Prevalence and risk factors of urinary incontinence among Chinese women in Shanghai. Int J Clin Exp Med. 2014;7(3):686-96.

22. Aydin Y, Hassa H, Oge T, Yalcin OT, Mutlu FS. Frequency and determinants of urogenital symptoms in postmenopausal Islamic women. Menopause. 2014;21(2):182-7.

23. Fritel X, Ringa V, Quiboeuf E, Fauconnier A. Female urinary incontinence, from pregnancy to menopause: a review of epidemiological and pathophysiological findings. Acta Obstet Gynecol Scand. 2012;91(8):901-10.

24. Oliveira C, Seleme M, Cansi PF, Consentino RF, Kumakura FY, Moreira GA, et al. Urinary incontinence in pregnant women and its relation with sociodemographic variables and quality of life. Rev Assoc Med Bras. 2013;59(5):460-6.

25. WHO Statement on caesarean section rates. Reprod Health Matters. 2015;23(45):149-50. 
26. Brasil. Ministério da Saúde. Departamento de Informática. http://tabnet.datasus.gov.br/cgi/tabcgi. exe?idb2012/f08.def. 2015.

27. Higa R, Lopes M. Why the nursing staff professionals with urinary incontinence do not seek for treatment. Rev Bras Enferm. 2007;60(5):503-6.

28. Guarisi T, Pinto-Neto A, Osis M, Pedro A, Costa-Paiva L, Faúndes A. The Search of Medical Care by Women with Urinary Incontinence. Rev Bras Ginecol Obstet. 2001;23(7):439-43.

29. Palmer $M H$, Fitzgerald S. Urinary incontinence in working women: a comparison study. J Womens Health (Larchmt). 2002;11(10):879-88.

30. Reymert J, Hunskaar S. Why do only a minority of perimenopausal women with urinary incontinence consult a doctor? Scand J Prim Health Care. 1994;12(3):180-3.

31. Higa R, Rivorêdo C, Campos L, Lopes M, Turato E. Vivências de mulheres brasileiras com incontinência urinária. Texto Contexto - Enferm. 2010;19(4):627-35.
32. Figueiredo E, Baracho S, Vaz C, Sampaio R. Educação de funcionárias de unidade básica de saúde acerca da atenção fisioterapêutica na incontinência urinária: relato de experiência. Fisioter Pesq. 2012;19(2):103-8.

33. Walker GJ, Gunasekera P. Pelvic organ prolapse and incontinence in developing countries: review of prevalence and risk factors. Int Urogynecol J. 2011;22(2):127-35.

34. Dumoulin C, Hay-Smith EJ, Mac Habee-Seguin G. Pelvic floor muscle training versus no treatment, or inactive control treatments, for urinary incontinence in women. Cochrane Database Syst Rev. 2010;(1):CD005654.

35. Seshan V, AlKhasawneh E, Hashmi IHA. Risk factors of urinary incontinence in women: a literature review. Int J of Urol Nurs 2016;10(3):118-26.

Received on $05 / 25 / 2016$

Recebido em 25/05/2016

Approved on 05/16/2017

Aprovado em 16/05/2017 